\title{
Gymnosperms from the Lower Cretaceous Crato Formation (Brazil). I. Araucariaceae and Lindleycladus (incertae sedis)
}

\author{
Lutz Kunzmann'1, Barbara A. R. Mohr ${ }^{2}$ \& Mary E. C. Bernardes-de-Oliveira ${ }^{3}$
}

With 1 figure and 8 plates

\begin{abstract}
Fossil conifers from the Early Cretaceous, most likely late Aptian, Crato Formation were studied. The excellent preservation of several of those fossils allowed detailed investigations of the leaf epidermis by light microscope (LM) and by scanning electron microscope (SEM). Members of two conifer taxa were recognized: The Araucariaceae are represented by a female cone of cf. Araucaria spec. A juvenile cone (Araucariostrobus spec.) and sterile foliage shoots of Brachyphyllum obesum might be attributed to the Araucariaceae as well. The morpho-genus Lindleycladus (incertae sedis) is represented by foliage shoots. The occurrence of Lindleycladus is the first record of this extinct morpho-genus in the Southern Hemisphere. Anatomical features of these conifers are interpreted as adaptations to a warm seasonally dry climate. Taphonomic problems concerning these conifer remains are discussed.
\end{abstract}

Key words: Fossil conifers, leaf epidermis, Araucariaceae, Lindleycladus, Early Cretaceous, Crato Formation, Brazil.

\section{Zusammenfassung}

Fossile Koniferen aus der unterkretazischen, höchstwahrscheinlich oberaptischen Crato Formation wurden untersucht. Die ausgezeichnete Erhaltung einiger Exemplare gestattete die Analyse von Blattepidermen mittels Licht- und Rasterelektronenmikroskop. Vertreter zweier Koniferentaxa wurden nachgewiesen: Araucariaceae kommen mit einem weiblichen Zapfen von cf. Araucaria spec. vor. Ein juveniler Zapfen (Araucariostrobus spec.) und sterile Zweige mit der Beblätterung der MorphoSpecies Brachyphyllum obesum werden unter Vorbehalt ebenfalls zu den Araucariaceae gestellt. Vegetative Organe der Morpho-Gattung Lindleycladus (incertae sedis) sind ebenfalls erhalten. Das Vorkommen von Lindleycladus ist ein erster Nachweis dieser fossilen Morpho-Gattung in der Südhemisphäre. Anatomische Merkmale dieser Koniferen werden als Anpassungen an ein warmes, saisonal trockenes Klima gedeutet. Im Zusammenhang mit den Koniferenresten werden taphonomische Probleme diskutiert.

Schlüsselwörter: Fossile Koniferen, Blattepidermis, Araucariaceae, Lindleycladus, Untere Kreide, Crato Formation, Brasilien.

\section{Introduction}

During the Early Cretaceous many conifer families, such as the Araucariaceae, Podocarpaceae, Cupressaceae s. l. (including Taxodiaceae), and Cheirolepidiaceae were present worldwide. While the Cheirolepidiaceae are now extinct, Araucariaceae and Podocarpaceae grow mainly in the Southern Hemisphere. There are several exceptions e.g. Agathis extends to Maleysia and the Phillipines, Nageia occurs in Asia as far as south- ern Japan, Afrocedrus grows in Ethiopia and the Podocarpaceae Dacrycarpus and Dacrydium reach SE-Asia (Page 1990).

Earlier studies on Mesozoic conifers were focused mostly on the Northern Hemisphere, however, during the last decades Southern Hemisphere conifers were studied intensely as well (Hill \& Brodribb 1999; see below). High latitude Cretaceous microfloras from the Antarctic Peninsula area, the Kerguelen Plateau, and Australia contain pollen of various Podocarpaceae s. 1.,

\footnotetext{
1 Museum of Mineralogy and Geology of the State Collections of Natural History Dresden, Königsbrücker Landstr. 159, 01109 Dresden, Germany. E-mail: Lutz.Kunzmann@snsd.smwk.sachsen.de

${ }^{2}$ Museum of Natural History of the Humboldt University Berlin, Department of Paleontology, Invalidenstrasse 43, 10115 Berlin, Germany. E-mail: barbara.mohr@museum.hu-berlin.de

${ }^{3}$ Institute of Geosciences, University of São Paulo, Cidade Universitária, Rua do Lago 562, São Paulo, CEP 05508-080, Brazil and Laboratory of Geosciences of the University of Guarulhos, Brazil. E-mail: maryeliz@usp.br Received March 2004, accepted June 2004
} 
such as Podocarpus, Microcachrys, Dacrydium, and Phyllocladus of the Phyllocladaceae (Cookson \& Pike 1953, Dettmann et al. 1992). Macrofloras reflect the importance of conifers in the southern vegetation as well. In the late Albian of Alexander Island various species of Araucariaceae, Podocarpaceae and Cupressaceae s. 1., and morpho-genera such as Podozamites, Elatocladus, Brachyphyllum and Pagiophyllum were identified which make up $15 \%$ of the species diversity of this site (Cantrill \& Falcon-Lang 2001). From Early Cretaceous Australian strata several araucarian species with various leaf types were described (Cantrill 1992). Patagonian Mesozoic conifer remains comprise several cones organically attached to vegetative structures and include Podocarpaceae, Cheirolepidaceae, and Araucariaceae (e.g. Archangelsky 1994, Calder 1953, Stockey 1982, 1994). Floras from low latitude South America are less well known (see below), reports exist only from the Crato and Santana Formations of Brazil and from Colombia (e.g. Pons et al. 1992).

This study is focussed on conifer specimens with preserved organic matter and on slabs with partly silicified plant remains from the late Aptian Crato Formation of Brazil and thus adds information on conifer taxa of Southern Hemisphere low latitudes. Descriptions of the epidermis anatomy of leaf taxa are given, which have been known from this flora as morpho-genera (Duarte 1985). In addition, we present preliminary results on conifer taxa of which the reproductive structures are preserved.

\section{The Flora of the Crato Formation}

Plant fossils and sporomorphs from the Crato Formation have been known for many decades, and several papers on the flora have been published to date (Barreto et al. 2000. Duarte 1985, Maisey 1991, Lima 1978, Lima et al. 1989, Mohr \& Friis 2000, Mohr \& Rydin 2002, Pons et al. 1992). The Crato flora comprises a diverse assemblage of free-sporing plants, various gymnosperms such as cycadophytes, gnetophytes (Osborn et al. 1993, Pons et al. 1992, Rydin et al. 2003, Mohr et al. 2004) and conifers (Duarte 1985 ) in addition to a variety of angiosperms (Mohr \& Friis 2000). In total about 70-80 species have been recognized, of which more than 20 taxa are thought to represent angiosperms, mostly magnoliid dicotyledons (Mohr \& Eklund 2003, Mohr \& Bernardes-de-Oliveira, in press).
The plants are thought to be mainly from terrestrial environments, but there are also a few putative aquatic elements.

The conifer component from the Crato and Santana Formations was previously known mainly from the pollen record, but also from several megaremains. Araucariaceae are represented by pollen of the Araucariacites morphospecies (Lima 1979) and by araucarian cone scales (Martill et al. 1993). Lima (1979) recognised Podocarpaceae by its pollen. Leafy shoots of Podozamites sp. (incertae sedis) which might belong to Lindleycladus (see below) are reported by Duarte (1985) and by Martill et al. (1993). Two previously described Brachyphyllum morphospecies, B. obesum Heer and B. castilhoi Duarte were not assigned to a family due to the lack of diagnostic epidermal features. These taxa are also known from the Albian Santana Formation of the same basin (Martill et al. 1993). The extinct family Cheirolepidiaceae is represented in the flora by pollen of the genus Classopollis Pflug (Lima 1979) and by vegetative shoots of the morpho-genus Pseudofrenelopsis Nathorst in Felix \& Lenk, 1893 emend. Watson, 1977. This taxon is present in the Crato as well as in the Santana Formation (Bernardes-de-Oliveira, oral comm.). Another cheirolepidiacean taxon, Tomaxellia Archangelsky 1963, previously described from Patagonia (Archangelsky 1963, 1966, 1968) has been observed as well (present in the collection of the MfN, Berlin) and will be described in more detail in a forthcoming paper. In addition to those taxa cited several undetermined conifer remains have been mentioned from the Crato Formation, such as "small cones, incertae sedis" (Martill et al. 1993).

\section{The fossil record of selected conifer families in South America}

Today four conifer families grow in the southern hemisphere, three of them in South America: Araucariaceae, Cupressaceae and Podocarpaceae. In addition, in the geologic past the extinct Cheirolepidiaceae were present. Here, we summarise briefly the fossil record of these families in South America, except for the Cupressaceae s. l. which seem to be irrelevant for this paper.

The Araucariaceae contain three extant genera, Agathis, Araucaria and Wollemia (Farjon 1998). While the fossil record of Agathis and Wollemia seems to be restricted to Australia and New Zealand (Chambers et al. 1998, Enright \& Hill 
1995), Araucaria was undoubtedly present in the Mesozoic of South America.

The section Araucaria of the genus Araucaria, with two extant species in South America, is represented in the fossil record by leaf remains from the Tertiary of the Rio Negro, Argentina (Menendez \& Caccavari 1966, Stockey 1994). The section Bunya is restricted to a single modern species in Queensland (Australia), but was more diverse and widespread during the Mesozoic (Wilde \& Eames 1952, Stockey 1994). Included in this group are cones of Araucaria mirabilis from the Jurassic Cerro Cuadrado Petrified Forest of Patagonia, Argentina (Stockey 1994), and probably cones of $A$. alvarezii from the Lower Cretaceous of the Chubut Province, Patagonia, Argentina (Dernbach \& Jung 2002). From the same area wood, male cones and seedlings of Araucaria are known (Stockey 1994). Araucarian cone scales and pollen of Araucariacites have been reported previously from the Lower Cretaceous Crato Formation (Martill et al. 1993). Other extant sections have not been recognized in the fossil record of the South American Mesozoic. Another, now extinct section, Yezonia, was originally established for a fossil Araucaria with Brachyphyllum-like foliage from Upper Cretaceous material of Japan (Ohsawa et al. 1995).

The Podocarpaceae were relatively diverse in the Mesozoic of the Southern Hemisphere, comprising several now extinct, but also living taxa (Enright \& Hill 1995). Five podocarp genera with 16 species grow today in South America (Enright \& Hill 1995). The Podocarpaceae are divided into genera with scale-like or awl-like adult leaves and genera with lanceolate or ovate, dorsiventrally flattened leaves. The latter group contains the genera Retrophyllum and Nageia which bear leaves without a single distinct midrib (Page 1989, 1990). Two of the six extant species of Retrophyllum are native to South America, while four are native to New Caledonia and Malesia (Page 1990). Retrophyllum might have been present in the Tertiary of South America. Extant Nageia is restricted to Asia and its evidence in the fossil record is not certain (Enright \& Hill 1995).

Among the genera with lanceolate leaves and a single midrib only Podocarpus is present in the modern flora of South America. Podocarpus and other related podocarps are reported from the Tertiary of South America (Florin 1963), and Podocarpus wood from the Cretaceous of the Antarctic Peninsula area (Falcon-Lang \& Cantrill 2000). The remaining extant genera of Podocarpa- ceae in South America, Saxegothea, Prumnopitys and Dacrydium bear scale-like or awl-like leaves and seem to be not relevant for this study.

Podozamites, Lindleycladus, Angariella belong according to Harris (1979) to the poorly defined family Podozamitaceae which consisted of several vegetative and of several fertile morpho-genera (Swedenborgia, Cycadocarpidium). At present Swedenborgia and Cycadocarpidium are referred to the Voltziaceae-Taxodiaceae clade (Grauvogel-Stamm 1978), so that the vegetative morphogenera mentioned are in fact conifers of unknown affinity (incertae sedis). In the Mesozoic of South America impressions of Podozamites are recorded (e.g. Berry 1945, Duarte 1985, Van Waveren et al. 2002), but they might partly belong to Lindleycladus (see below).

The extinct Cheirolepidiaceae are widespread during the Mesozoic both in the Northern and Southern Hemispheres. A more detailed account of South American members of the Cheirolepidiaceae will be given in a forthcoming paper.

\section{Material and methods}

The conifers described in this paper come from the Crato Formation of the Araripe Basin, which contains Late Jurassic to late Early Cretaceous sedimentary sequences. This formation is the lowermost part of the Araripe Group, and based on palynological data is considered to be probably late Aptian in age (Arai et al. 2001, Doyle 1992, Lima 1978, Pons et al. 1990, Pons et al. 1992). For a more detailed geographical and geological descriptions see Maisey (1991), Martill et al. (1993), Mohr \& Friis (2000) and Regali (1989).

The yellowish to light greyish brown bedded limestone (Plattenkalk) is mined commercially in the area of Santana do Cariri in Northeastern Brazil, and delivers a wide array of fossils, invertebrate and vertebrate faunas, as well as a diverse flora. The plant fossils are of varying preservation.

Conifer remains constitute a relatively large part of the flora. They are mainly represented by sterile foliage shoots, reproductive organs are less frequent. As for the other components of the flora most of the conifers remains are preserved as impression fossils with or without a thin layer of iron oxide, which replaced the original organic matter (Pl. 1). The sediments are not fine grained enough to yield information about the cellular structure from these impressions by casts or peels. A few shoots where the secondary xylem of the main axis and leaves were fully replaced by iron oxide are an exception (Pl. 2: 3-4; MfN PB 1999/449; 1999/475). These specimens allow studies of the cellular structure of the leaf epidermis. Rare specimens with a different preservation seem to come from the lower part of the section (Martill, pers. comm.). There plant fossils occur which are partly silicified/petrified or contain coalified organic matter (Pl. 2: 1-2; MfN PB 1999/468).

The fossils were studied under a Leica MZ APO Microscope with camera lucida. The photgraphs were taken with a Nikon 801 camera and a $60 \mathrm{~mm}$ Nikkor macro-objective. Agfa PAN APX 25 film was used for the photographs.

To obtain leaf cuticles small parts of lateral shoots or single leaves were removed from the specimen. Afterwards they were macerated 1-4 minutes in Schultze solution, then neu- 
tralized with $\mathrm{NH}_{4} \mathrm{OH}$ and washed with destilled water. Some of the cuticles were mounted on stubs for SEM studies. some were coloured with Safranin to make slides for LM studies. Cuticle slides were studied under a Leica Aristoplan Microscope. For SEM studies the samples were sputtered 4 minutes with Goldpaladium. For studying iron oxide material with SEM small pieces of material were removed from the specimen, directly mounted on stubs and sputtered also 4 minutes with Goldpaladium. The SEM-photographs were taken on a LEO 1450VP SEM.

The material described here was collected from about a dozen open cast pits several $\mathrm{km}$ south of the town of Nova Olinda, between Nova Olinda and Santana do Cariri, and is housed at the Paleobotanical Collection of the Museum of Natural History, Berlin (Museum für Naturkunde zu Berlin = MfN PB)

In the taxonomy and the systematics of conifers we follow Page (1990) and Farjon (1998)

\section{Descriptions of reproductive organs}

\section{Araucariaceae Henkel \& Hochstetter, 1865}

\section{Araucaria Jussieu, 1789}

\section{cf. Araucaria spec. (strobilus, squamata)}

Pl. 1: 1-2; Fig. 1A, B

Description. The ovulate cone (specimen MfN PB 2002/1049; Pl. 1: 1), preserved in a longitudinal cross section, is laterally flattened and $85 \mathrm{~mm}$ long and $48 \mathrm{~mm}$ in diameter. Only a few parts (seeds, parts of the scales) are permineralized with silica, while most of the scales and the cone axis are preserved as iron oxide. The cone peduncle is short and thick, $16 \mathrm{~mm}$ long and $10 \mathrm{~mm}$ in diameter, it bears no leaves or leaf cushions. Internally, a central cylindrical cone axis contains many thin longitudinally orientated resin canals. These resin canals proceed into the scale complexes. Numerous tectate brownish cone scale complexes are densely helically inserted and diverging at $90^{\circ}$ from the axis. Most of the scales, which were probably of a leathery consistence, are deformed. Only a few scales at the cone apex show a typical araucarioid shape: the scales are cuneate, widest in the distal part and up to $16 \mathrm{~mm}$ long and $8 \mathrm{~mm}$ wide. The distal end is rounded to cuneate and prolongs into a short process.

More than 10 resin canals, which branch out, are visible at each scale. It seems that externally the cone scale complexes are abraded. The scales at the cone apex lack any imprints of seeds or holes where the seeds were inserted at the scales. Some of the scales, which are laterally attached at the cone, contain grey-black small elliptical bodies, which are most likely silicified seeds (Fig. 1A). Although the scales are quite densely attached and the preservation is not optimal, it is obvious that there is a single seed per scale. The seeds are probably wingless.

Discussion. The shape and size of the cone, numerous helically arranged cone scale complexes, and one seed per scale show the general characteristics of ovulate cones of the family Araucariaceae (Page 1990). The probably wingless seeds indicate affinities to the genus Araucaria, though the preservation is not complete enough to be really sure (Stockey 1982, 1994). Features such as the separation between bract and ovuliferous scale (distinct ligula) and wings of the scale complex, are not preserved. A completely fused bract-scale-complex, and a winged seed would imply a species of Agathis Salisbury, 1807 or Wollemia Jones, Hill \& Allen, 1995. At present ovulate cones of Agathis and of Wollemia have not been discovered in the Mesozoic fossil record (Stockey 1994).

Araucarian ovulate cones fully desintegrate at maturity on the tree into the scale-seed-complexes. Therefore, it can be assumed that complete ovulate cones such as the one under discussion were shed before maturity. The immaturity complicates any size comparison between fossil species. Araucaria mirabilis (Spegazzini, 1924) Windhausen, 1931 from the Upper Jurassic of the Cerro Quadrado Petrified Forest, province Santa Cruz, Patagonia (Argentina) has spherical to slightly elliptical cones of 25 to $90 \mathrm{~mm}$ in length and up to $90 \mathrm{~mm}$ in width (Dernbach \& Jung 2002). Araucaria alvarezii Dernbach \& Jung, 2002 from the Lower Cretaceous of the province Chubut, Patagonia (Argentina) has more elongated cylindrical cones, which reach $200 \mathrm{~mm}$ in length and 70 to $110 \mathrm{~mm}$ in width (Dernbach \& Jung 2002). Cones of two species of Araucariostrobus Krasser, 1921 from the Lower Cretaceous of the Leiva region, Columbia, which can not be assigned with certainty to the Araucariaceae, are sub-spherical in shape and $70 \mathrm{~mm}$ long $\times 60 \mathrm{~mm}$ wide respectively $70 \mathrm{~mm}$ long $\times 50 \mathrm{~mm}$ wide (Van Waveren et al. 2002).

Isolated cone scales such as the specimen MfN PB 1999/428 (Pl. 1: 3; Fig. 1B) most likely belong to the morpho-genus described above. This scale fully corresponds with such cone scales from the apex of the specimen MfN PB $2002 / 1049=$ cf. Araucaria spec. The scale is cuneate in shape, $18 \mathrm{~mm}$ long and $12 \mathrm{~mm}$ wide, widest at the distal end. The distal margin is rounded and prolongs into a short acute process. 


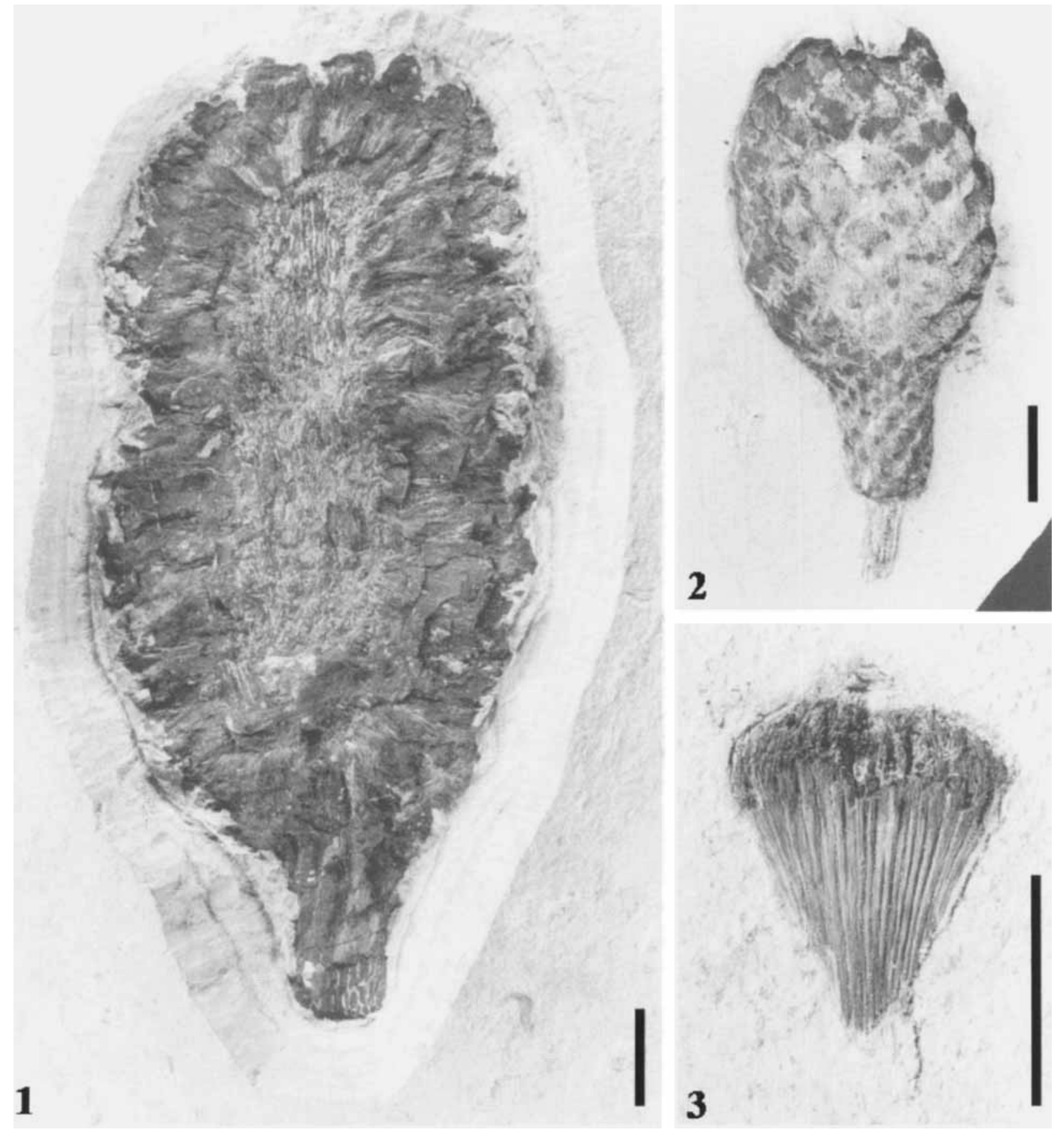

Plate 1. Reproductive organs. 1, cf. Araucaria spec., complete seed cone, MfN PB 2002/1049; 2, Araucariostrobus spec., MfN PB 1999/2290 (scale bars = $1 \mathrm{~cm}$ ); 3, cf. Araucaria spec., isolated cone scale, MfN PB 1999/428.

There are about 20 thin parallel ribs on the surface of the basal part, which may be interpreted as empty resin canals.

Similar cone scales, when found in the Upper Cretaceous of the Northern Hemisphere are assigned to "Dammara" borealis Heer, 1882 (see Němejc \& Kvaček 1975, Kunzmann 1999). The affinity of scales of the type "Dammara" borealis is still uncertain, because in all known fossils the seed(s) have been already detached. In our specimen the scale originated with great certainty from an araucarian cone.

\section{aff. Araucariaceae Henkel \& Hochstetter, 1865}

Araucariostrobus Krasser, 1921

\section{Araucariostrobus spec.}

Pl. 1: 2; Fig. 1C

Description and remarks. Among various undetermined cones of the Crato flora, several are attached to leafy shoots. Specimen MfN PB 1999/2290 (Pl. 1: 2) shows a most likely female (male cones of Araucariaceae are 


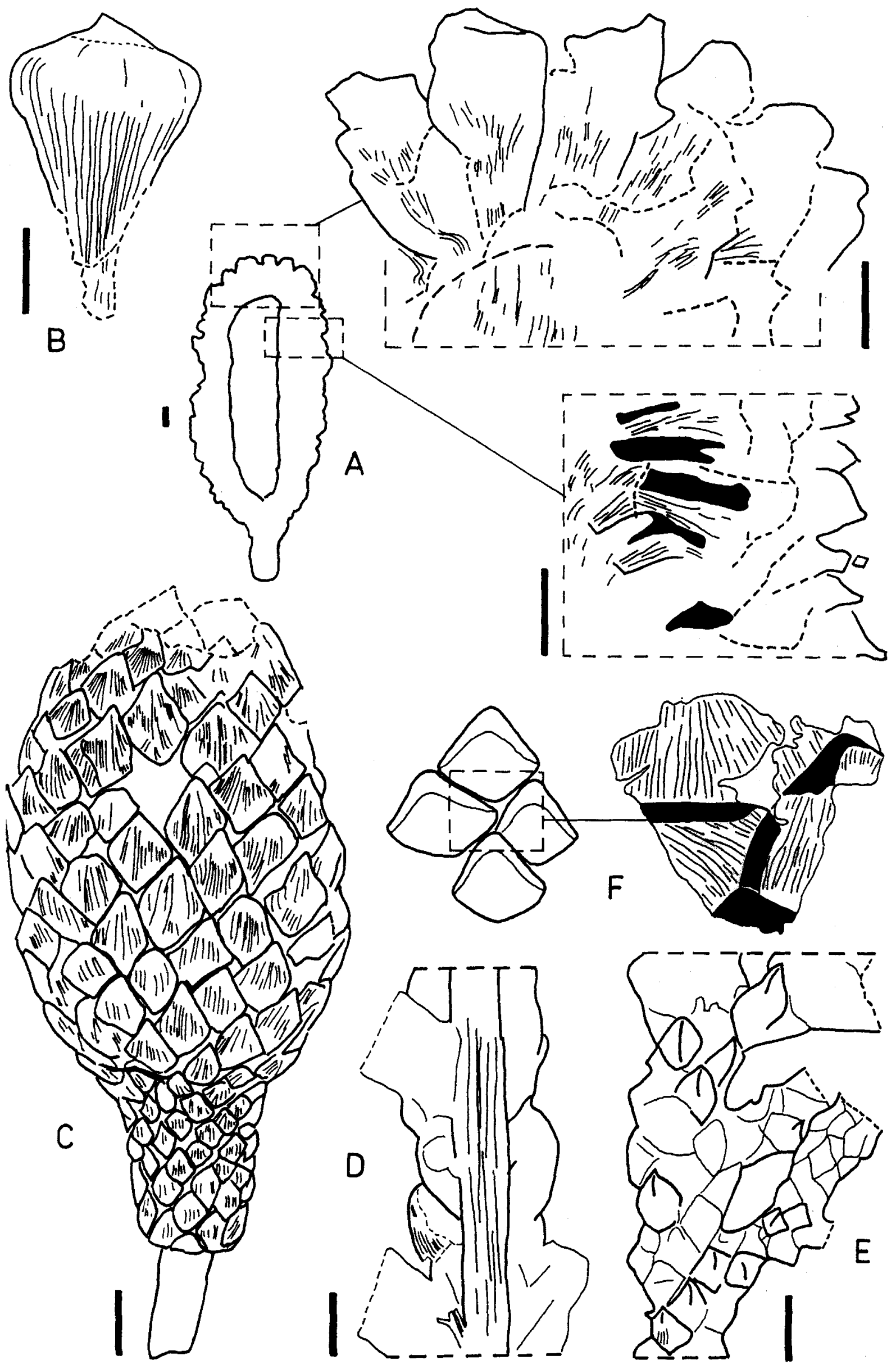


generally more elongate in shape) juvenile or immature cone structure attached to a foliage shoot with leaves of the Brachyphyllum type. It is preserved as an impression with a thin layer of iron oxide. This elliptical cone is $38 \mathrm{~mm}$ long and in the median part $28 \mathrm{~mm}$ in diameter. About 56 small rhombic tectate bracts with an acute apex are helically and densely arranged. These bracts are up to $9 \mathrm{~mm}$ long and up to $6 \mathrm{~mm}$ wide. Their surface is characterized by dense and fine longitudinal ribs. The shoot is densely covered with the typical rhombic cushions of Brachyphyllum leaves, except the lower part, where the leaves are completely removed from the axis. There, the real thickness of the axis is visible $(4 \mathrm{~mm}$ in diameter), while the leafy part is $10 \mathrm{~mm}$ in diameter.

The leaves grade into the bracts of the cone. This gradual change from the leaves to the bracts indicates ontogenetically young cones. There are no features to decide whether it is a male or a female organ. The shape of the cone, number and gross morphology of the bracts infer that it is of araucarian affinity. This presumption is strengthened by the anatomical features of the leaves, which will be described below. If the cone belongs to Araucariaceae, this organ is most likely female because male cones of Araucariaceae are generally more elongate in shape.

For conifer cones with affinities to the Araucariaceae the morpho-genus Araucariostrobus is used, which was originally erected for female cones from the Jurassic of Nikolsk-Ussurijsk in the Far East of Russia (Krasser 1921: 221). However, the original description lacks any diagnostic details and therefore the name Araucariostrobus needs revision. It is used today generally for araucarioid cones of which only the gross morphology is preserved (e.g. Van Waveren et al. 2002).

\section{Vegetative shoots}

\section{cf. Araucariaceae Henkel \& Hochstetter, 1865}

\author{
Brachyphyllum Lindley \& Hutton, 1836 emend. \\ Harris, 1979
}

\section{Brachyphyllum obesum Heer, 1881 sensu Duarte, 1985}

Pl. 2-6; Figs 1D-F

Description. Twigs consist generally of up to 4 branching orders (Pl. 5: 1-2). All branching orders are characterized by densely covering, helically arranged, slightly imbricate leaves or rhomboidal leaf cushions. Main axes are $12-15 \mathrm{~mm}$ wide, sub-main branches $6-10 \mathrm{~mm}$, penultimate and ultimate branches $3-5 \mathrm{~mm}$ wide. Generally, $2 / 3$ of the width consists of leaves. Lateral branches of each order are attached oppositely or slightly suboppositely at their axes and aligned with a horizontal plane (Pl. 5: 3). Angles between main and lateral branches vary between $45^{\circ}$ and $75^{\circ}$. Shoots are of a quite regular habit.

The determination of the contact parastichies at the studied material is complicated when using the method of Watson et al. (1987). Parastichy numbers for specimen MfN PB 1999/465 are probably $14+6$ (main axis with a width of 14,4 mm) (Pl. 5: 5); for specimen MfN PB 1999/ 472 probably $8+10$ (main axis with a width of $15 \mathrm{~mm}$ ) (Pl. 5: 1-2); for specimen MfN PB 1999/ 452 probably $10+12$ (main axis with a width of 11,25 mm) (Pl. 5: 3-4); for specimen MfN PB 1999/471 probably $4+2$ (penultimate branch with a width of $6,7 \mathrm{~mm}$ ).

Leaves of the penultimate and ultimate branches are of the Brachyphyllum type: free part adpressed, apex acute with a rounded tip, base of the blade rounded. The leaf margin is built of a denticulate frill formed by a single layer of cells pointing obliquely forwards (Pl. 4: 2). Total length of the leaf is at most as long as width of leaf cushion. Free part of the leaf is as long as one third of the total length of the leaf. Leaf blades are slightly keeled and convex in shape. Leaves from the Crato specimens are up to $10 \mathrm{~mm}$ long and up to $6 \mathrm{~mm}$ wide. The leaves don't seem to be dimorphic, but show a gradual variation in leaf size, especially in the size of the free part of the leaves from penultimate shoots. The leaf thickness of the penultimate shoot is visible in a longitudinal section at specimen MfN PB 1999/475 (Pl. 2: 4). The leaves are $4 \mathrm{~mm}$

Fig. 1. Camera lucida drawings of selected specimens. A, cf. Araucaria spec., seed cone, detailed drawings of the apical and the lateral part, black areas = seeds, MfN PB 2002/1049; B, cf. Araucaria spec., isolated cone scale, MfN PB 1999/428; C, Araucariostrobus spec., MfN PB 1999/2290; D, Brachyphyllum obesum Heer, 1881, detail of a leafy shoot in longitudinal section, MfN PB 1999/475; E, F Brachyphyllum obesum Heer, 1881, specimen with coalified organic matter, MfN PB 1999/468, $\mathbf{E}$, detail of the leafy shoot, $\mathbf{F}$, right: leaf cuticle after maceration, showing abaxial files of stomata, black areas $=$ overlying adaxial cuticles $(10 \times)$, left: reconstruction of the leaves for orientation; (scale bars for $A-E=1 \mathrm{~cm}$ ). 

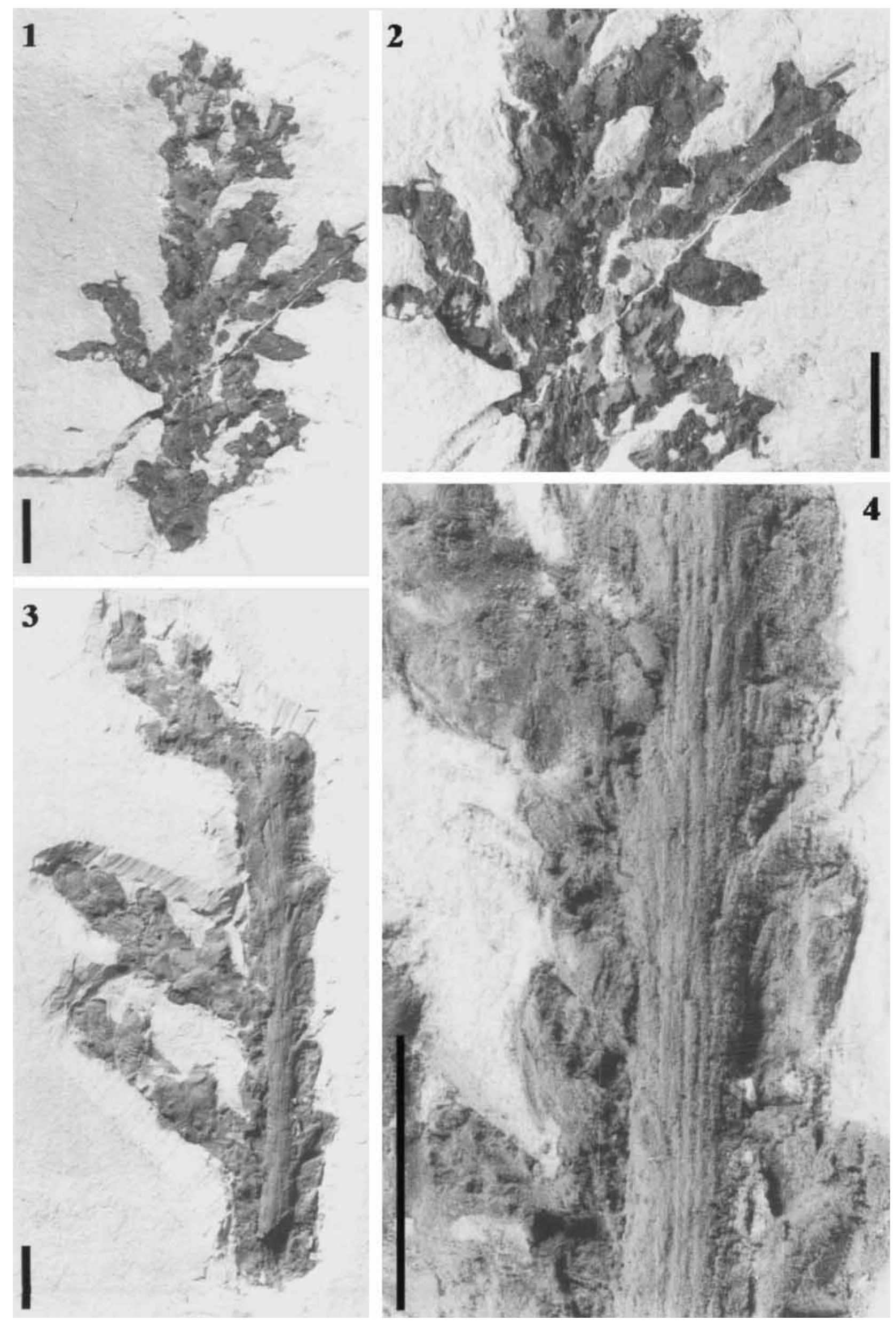
thick and rhombic in cross section and $10 \mathrm{~mm}$ long, the free part seems to be as half as long as the cushion. The apex is probably acute-obtuse. The free part of the blade spreads at an angel of $30^{\circ}-60^{\circ}$ from the axis, and straight or slightly curved forward to the axis. Thus the leaves at the main axis overlap in size with the definition for the morphogenus Pagiophyllum Heer, 1881 emend. Harris (Harris 1979: 23).

Leaves are amphistomatic with monocyclic to incompletely amphicyclic stomata; encircling cells are very rare. Specimen MfN PB 1999/449 bears exceptionally preserved leaf blades of iron oxide: the outer pits of the stomatal complexes are filled with the white or yellow sediment. This makes the distribution of stomata on the leaf epidermis clearly visible (Pl. 4: 3). Stomata of the abaxial side are placed in well defined longitudinal files. These files extend over the whole surface. Compression fossils exhibit relatively thick organic matter (coal) (specimen MfN PB 1999/468; Pl. 2; 1-2). Cuticles of these leaves are very thick and well preserved, therefore the whole topography of the epidermis can be described.

The adaxial side (Pl. 3: 4-5) is less cutinized than the abaxial one. Stomata are arranged in continuous or discontinuous rows. These rows are usually oriented longitudinally to the long axis of the leaf. One to 5 rows of ordinary epidermis cells are inserted between stomatal rows. The inner surface of the cuticle shows stomata surrounded by 4 to 6 subsidiary cells forming an oval ring. Within one stomatal row subsidiary cells of adjacent stomata are sometimes in contact but never shared. There is no typical difference between polar and lateral subsidiaries. Outer anticlinal walls of the subsidiary cells are markedly thickened forming a ring structure. Stomatal pits are narrowly oval in their outlines. Size of stomata: rings of subsidiaries are $80-88 \mu \mathrm{m}$ long $\times 44-54 \mu \mathrm{m}$ wide; outer pits are $28-36 \mu \mathrm{m}$ long $\times 8-16 \mu \mathrm{m}$ wide. Guard cells are lost during the maceration process; they are usually sunken into the epidermis layer. Ordinary cells are longitudinal or isodiametric in shape with thick, but straight or slightly curved anticlinal walls. They are arranged in continuous files. Periclinal surface without papillae.
The abaxial side (P1. 3: 1-3; Pl. 6) is distinguished by numerous longitudinal continuous rows of stomata. One to 4 rows of ordinary epidermis cells are inserted between stomatal rows. The orientation of stomata is mainly transversal to the long axis of the leaf, but longitudinal and oblique orientations also occur. Usually stomata of one row are transversally orientated over a longer section, only a few stomata with longitudinal or oblique orientation are intercalated. Inner cuticle surface: As at the adaxial side 4 to 6 subsidiary cells form a regular oval to circular ring, which surrounds a narrow oval to rectangular stomatal pit. It is not possible to distinguish polar and lateral subsidiaries. Within one row subsidiary cells of adjacent stomata are usually in contact but never shared. Size of stomata: rings of subsidiaries are $70-100 \mu \mathrm{m}$ long and $60-74 \mu \mathrm{m}$ wide, outer pits are $24-32 \mu \mathrm{m}$ long and $12-20 \mu \mathrm{m}$ wide. Ordinary epidermis cells are arranged in continuous longitudinal files, shape and development of the anticlinal walls as at the adaxial side. Outer cuticle surface: No papillae or Florin rings are visible. Subsidiaries are not or slightly sunken, guard cells are sunken into the leaf epidermis. Narrow oval pits are without a stomatal wax plug.

The xylem of the penultimate shoots is more or less three-dimensionally preserved without any diagenetic flattening in some of the specimens. The xylem of the axis in specimen MfN PB 1999/475, which was fully replaced by iron oxide, shows only tracheids, but no pitting under SEM.

Discussion. Most of the conifer remains from the Crato flora are sterile foliage shoots with leaves of the Brachyphyllum morphotype. For a classification of sterile foliage shoots of Mesozoic conifer it is most suitable to use the artificial morphogenus Brachyphyllum Lindley \& Hutton, 1836 emend. Harris, 1979, although various Brachyphyllum species can be ascribed to different conifer families, if their cuticle topography is known (Harris 1979). The morphogenus Brachyphyllum encloses spirally arranged scalelike leaves, if the length of the free part or the total height of the leaf and cushion is as long as or less than the width of the leaf cushion (Harris 1979: 4). It is difficult but not impossible to distinguish Brachyphyllum species only by their fea-

Plate 2. Brachyphyllum obesum Heer, 1881. 1-2, specimen with coalified organic matter, complete shoot and detail, MfN PB 1999/468; 3-4, specimen preserved in longitudinal section, organic matter is replaced by iron oxide, complete shoot and detail, real thickness of scaly leaves and xylem of the axis is visible, MfN PB 1999/475 (scale bars = $1 \mathrm{~cm}$ ). 

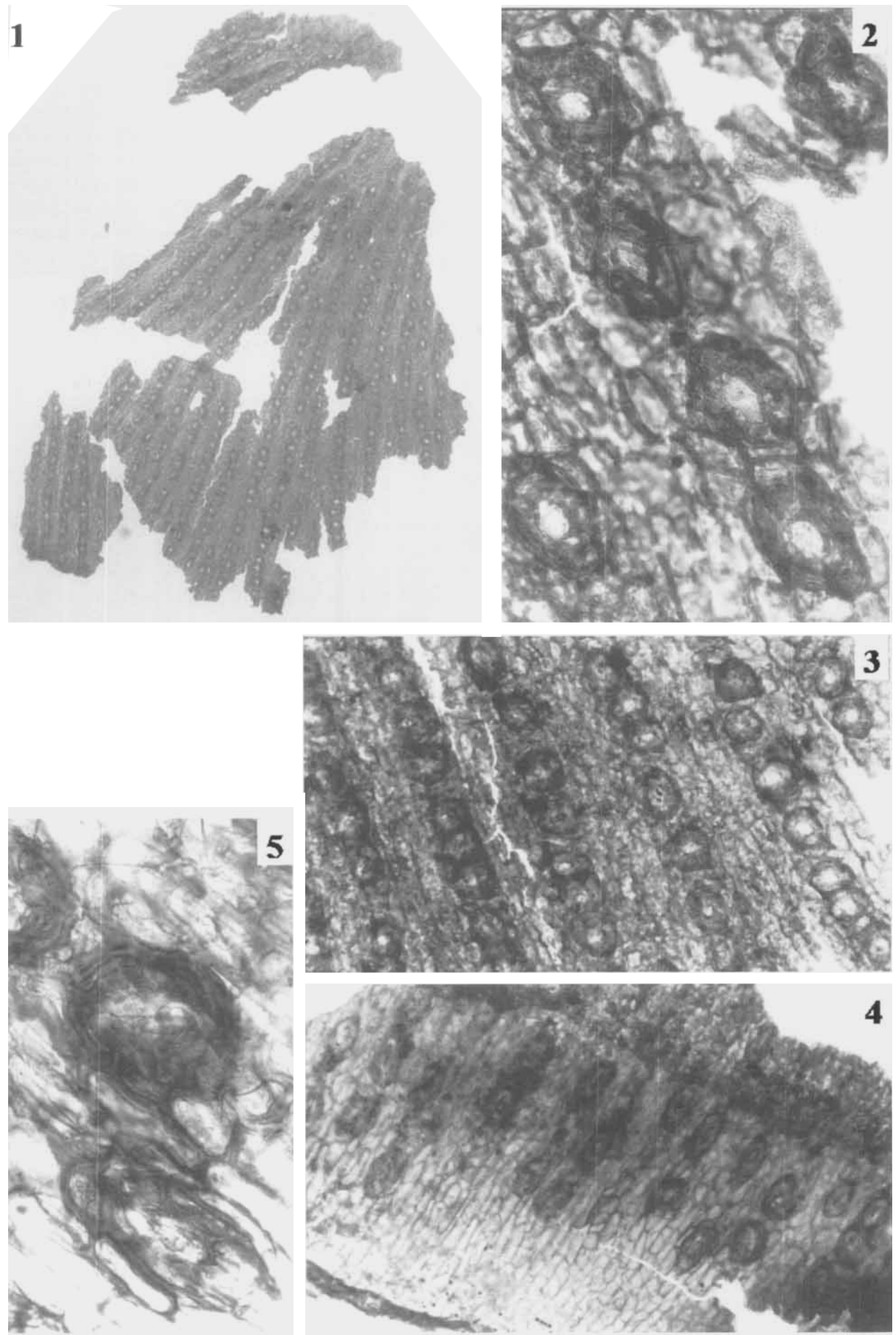
tures in gross morphology (leaf size, size of free part of the leaf, leaf margin; e.g. Harris 1979).

After Martill et al. (1993) two species of Brachyphyllum are known from the Crato flora, both described by Duarte (1985): B. obesum Heer, 1881 and B. castilhoi Duarte, 1985. Most of the Brachyphyllum material from the Crato Formation belongs to the morphospecies $B$. obesum, which was erected by Heer (1881) for sterile foliage shoots from the Cretaceous of Almargem, Portugal. Heer gave the following diagnosis: "Br. ramis alternis, ramulis numerosis, aggregatis, crassis, brevibus, apice obtusis, foliis rhombeis, dense imbricates, dorso leviter striatis." Strictly speaking this diagnosis was surely sufficient, but today it is too general. The abaxial striation might be the stomatal files. Due to this striation and to the gross morphology of the leaves Duarte (1985) named the Crato material B. obesum. The two specimens from which epidermis features were available at present belong to this type of Brachyphyllum foliage shoots. We follow Duarte in this study, but much more taxonomic work has to be done in the future. It is obvious that the epidermis features additionally described here have to be compared with the type material of B. obesum. Brachyphyllum castilhoi is characterized by a regularly pinnate branching system, claviform branchlets, abaxially keeled leaves with an acute apex and by the disposal of the leaves in ten lines on main axes and eight lines on branchlets (Duarte 1985). From the figures of the holotype this species is distinguished from $B$. obesum by its remarkable habit.

Brachyphyllum leaves with entire nonpapillate stomata in numerous stomatal files are ascribed to the Cheirolepidiaceae or to the Araucariaceae. It needs additional (supporting) evidence to attribute them surely to a family (Watson 1988: 425). The cuticle of Araucaria is characterized by stomatal wax plugs, more or less undulating anticlinal walls of the epidermis cells, and by the lack of Florin rings (Stockey 1994: 495). Our Crato Brachyphyllum resembles in some features Brachyphyllum mamillare Lindley \& Hutton, 1836 from the Yorkshire Jurassic Flora (Harris 1979). It also has nonpapillate slightly sunken stomata placed in conspicuous files equally distributed over the whole surface (Harris 1979: 8). B. mamillare is associated with cone scales of Araucarites philipsii Carruther, 1869, and with no doubt both organs belong to one fossil plant, which is a member of the Araucariaceae (Harris 1979: 14). Remains of fossil Araucaria seed cones that bear Brachyphyllum-like foliage are known from the Upper Cretaceous of Japan (Ohsawa et al. 1995). The extinct section Yezonia Ohsawa et al., 1995 was established for those specimens. In addition, the Crato flora yields several taxa of Classopollis Pflug, 1953 - the typical pollen of the members of Cheirolepidiaceae (Lima 1979). Therefore, it can't be excluded that there are members of the Cheirolepidiaceae among the Brachyphyllum specimens within the Crato flora.

\section{Incertae sedis}

\section{Lindleycladus Harris, 1979}

\section{Lindleycladus spec.}

Pl. 7-8

Description. Gross morphology: The leafy ultimate shoots are up to $30-130 \mathrm{~mm}$ long, they are probably caducous. The leaves are helically arranged probably in a simple helix and spreading all around. Gaps between leaf blades are variable, but they seem to be as wide as the blade. The leaf blades are more densely arranged at the top of the leafy shoot. Leaves are dorsiventrally flattened, lanceolate, straight, and scarcely petiolate. The distal end is tapering to an obtuseacute-rounded apex. The basal part is gradually leading into the short peduncle. Leaves are $32,5-133 \mathrm{~mm}$ long and $6-7,5 \mathrm{~mm}$ wide. The lamina are remarkably thick and fleshy, about $1 \mathrm{~mm}$ thick (Pl. 8: 2), with up to 22 thin longitudinally unforked ribs, only recognizable on impressions. They seem to be parallel veins.

The leaf epidermis of specimen MfN PB 1999/ 442 are excellently preserved as iron oxide, thus the distribution of stomata on the leaf epidermis is quite visible ( $\mathrm{Pl} .8: 3$ ). The leaves are hypostomatic.

Plate 3. Brachyphyllum obesum Heer, 1881, leaf epidermis, LM photographs of cuticle preparation slides, specimen MfN PB 1999/468. 1-3, abaxial cuticle; 4-5, adaxial cuticle; 1, almost complete abaxial side showing longitudinal stomatal files, preparation specimen MfN PB LM 1999/468-1 $(32 \times)$; 2 , detail of fig. 1: monocyclic to incomplete dicyclic stomata $(250 \times) ; \mathbf{3}$, detail of fig. 1: stomatal files showing orientation of stomata $(100 \times) ; \mathbf{4}$, almost complete adaxial side showing longitudinal stomatal files, preparation specimen MfN PB LM 1999/468-2 $(100 \times)$; 5, detail of fig. 4: adaxial stomata $(400 \times)$. 

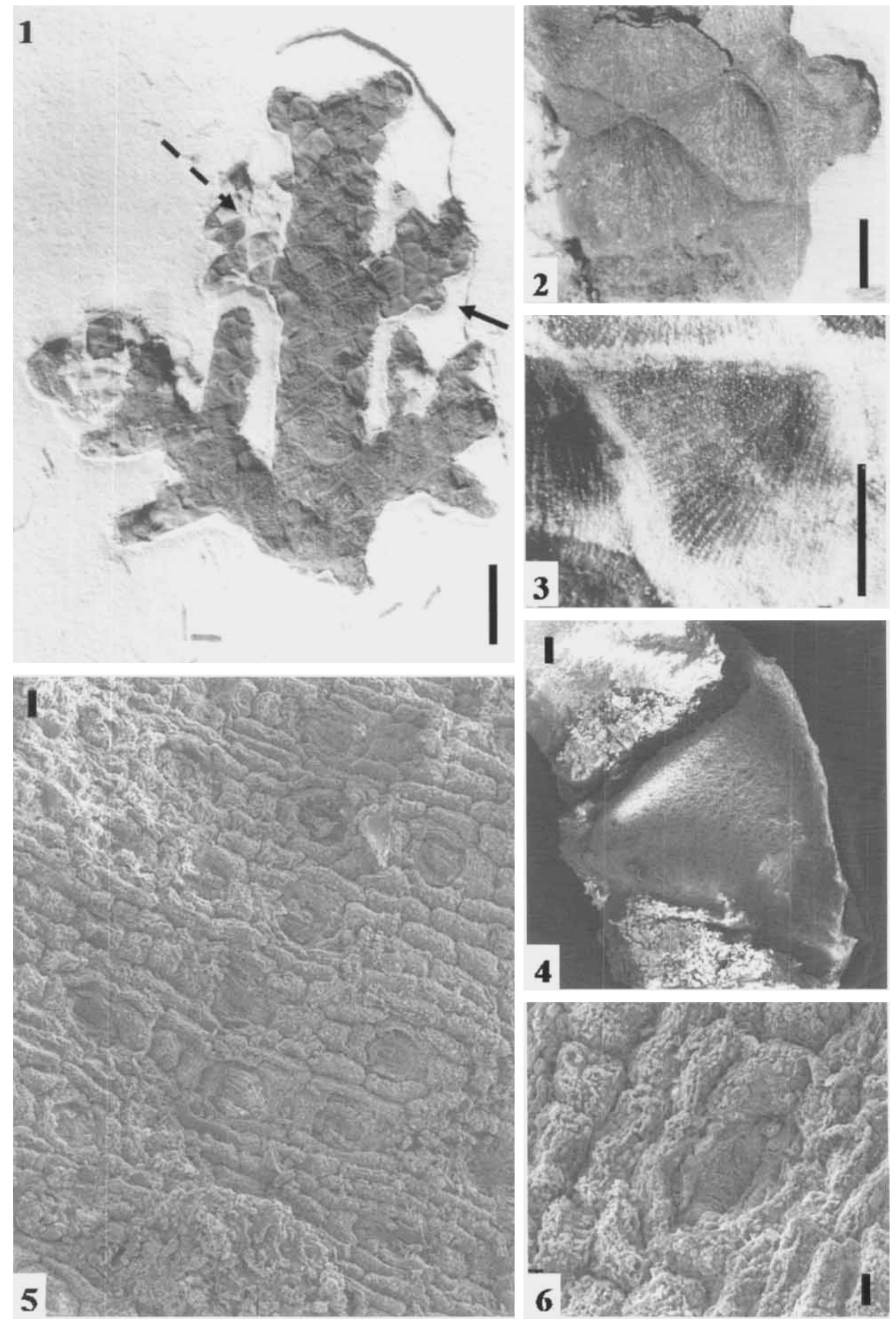
On the abaxial side stomata are placed in bands of 3 to 5 files, between the files in one band one row of ordinary epidermal cells is observed. These bands are less cutinised then other parts. Within one row subsidiary cells of adjacent stomata are never in contact. Pori are strictly longitudinally orientated. The outer cuticle surface shows incompletely amphicyclocytic stomata with 4-6 (7) subsidiaries. Guard cells are slightly sunken, but subsidiaries are exposed. Distance between two stomata of one row: 130-140 $\mu \mathrm{m}$; distance between two stomatal rows: 100$120 \mu \mathrm{m}$.

Between the stomatal bands are 4 to 6 rows of ordinary epidermis cells which probably correlate with the vein stripes. Ordinary epidermis cells are elongated and rectangular in shape with straight or slightly curved anticlinal walls. They are placed in simple longitudinal files. The whole epidermis lacks papillae.

On the inner surface (specimen MfN PB 2002/ 1052, pl. 7: 4-7) the rings of subsidiaries are oval, $72-84 \mu \mathrm{m}$ long $\times 52-60 \mu \mathrm{m}$ wide. The anticlinal walls of the subsidiaries are thin and curved. Polar subsidiaries are not elongated. Stomatal pits are oblong to oval, $28-36 \mu \mathrm{m}$ long $\times$ $12-20 \mu \mathrm{m}$ wide. Ordinary epidermis cells within the stomatal bands are more isodiametric then rectangular in shape, sometimes also polygonal. Size: $25-36 \mu \mathrm{m}$ wide and $1 \times$ to $3 \times$ longer then wide. Their anticlinal walls thin, straight or slightly curved. The periclinal surface shows irregularly arranged, circular forms, perhaps originated from crystal bodies.

On the adaxial side almost uniformly longitudinal files of ordinary epidermis cells with straight to slightly curved anticlinal walls are visible.

Discussion. These leafy shoots belong certainly to the conifers, because the stoma type is coniferous. This extinct leaf type might belong to conifer groups that share several characters with the fossil such as the Podocarpaceae Endlicher 1847, Agathis Salisbury, 1807, or the Podozamitaceae Němejc, 1950 (Podozamites Braun, 1843; Lindleycladus Harris, 1979).
There are only two genera of Podocarpaceae that have flattened, petiolate, long lanceolate to broadly elliptic leaves lacking a distinct midrib but with several fine parallel lengthwise veins (Page 1990). The leaves of Retrophyllum Page, 1989 are spirally arranged and obliquely inserted into opposite to subopposite and decussate whorls; regular pectinate rows on lateral shoots (Page 1990); leaves not longer than $30 \mathrm{~mm}$. $\mathrm{Na}$ geia Gaertner, 1788 has broadly ovate-elliptic leaves with many fine veins, leaves spirally arranged or in decussate pairs on leading shoots and opposite to subopposite and spreading on lateral shoots, 30-100 mm long (Page 1990: 339). Since the Crato remains show different features, they can not be assigned to any modern podocarp genus.

The genus Agathis (Araucariaceae) has similar petiolate, multi-veined leaves, but the arrangement and type of stomata are distinct (Stockey 1994), and therefore Agathis is also different from our Crato material.

The morphology of the leaves is most similar to Podozamites and to Lindleycladus, two vegetative morpho-genera of unknown affinity - no reproductive structures have been described yet of the Mesozoic and Early Cenozoic. Podozamites is distinguished from Lindleycladus by transversely orientated stomata arranged in files, while Lindleycladus has exclusively longitudinally orientated stomata arranged in narrow bands of a few files (Harris 1979: 145).

The Crato leaves resemble Lindleycladus lanceolatus (Lindley \& Hutton, 1836) Harris, 1979 in gross morphology, as well as in the arrangement and orientation of stomata. Thus there is no reason to doubt a southern hemisphere occurrence of Lindleycladus in the Cretaceous.

Lindleycladus is probably identical with Podozamites sp. from the Crato Formation, described by Duarte (1985), but since this description did not include a detailed analysis of cuticles, the affinity of those fossils remains unresolved. In the Crato flora this foliage type is less common than Brachyphyllum leafy shoots. Leaves of Podozamites spec. are reportet also from the Lower Cre-

Plate 4. Brachyphyllum obesum Heer, 1881: outer surface of a leafy shoot, organic matter is replaced by iron oxide, specimen MfN PB 1999/449. 1, complete shoot (scale bar $=1 \mathrm{~cm}$ ); 2, detail of fig. 1 (see arrow with entire line): leaves of penultimate and ultimate branches showing acute-obtuse apex and denticulate marginal frill (scale bar = $0,2 \mathrm{~mm}$ ); 3 , detail of fig. 1 (see arrow with dashed line): leaf of penultimate shoot, abaxial surface showing stomatal files by sedimentary plugs in the stomatal pits (scale bar $=0,2 \mathrm{~mm}$ ); 4-6, SEM photographs of the abaxial side of a leaf removed from an penultimate branch, preparation specimen MfN PB SEM 1999/449-4, 4, complete leaf (scale bar $=200 \mu \mathrm{m})$; 5 , detail of stomatal files (scale bar = 20 $\mu \mathrm{m})$; 6, single stoma with slightly sunken guard cells (scale bar $=10 \mu \mathrm{m}$ ). 


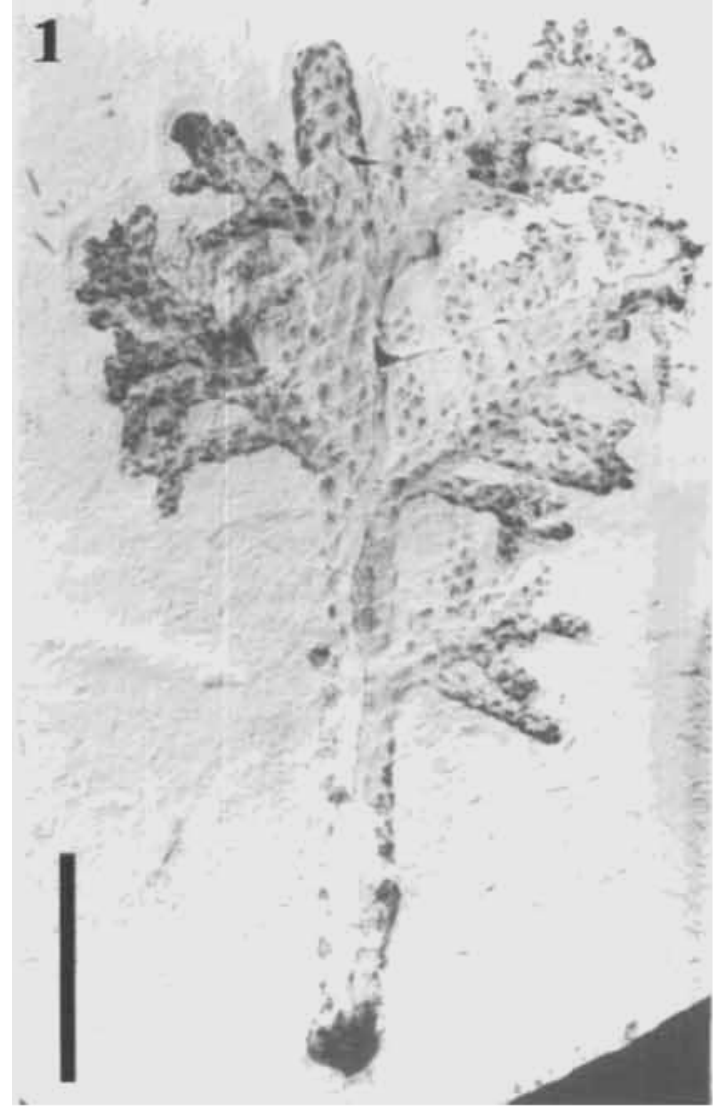

3
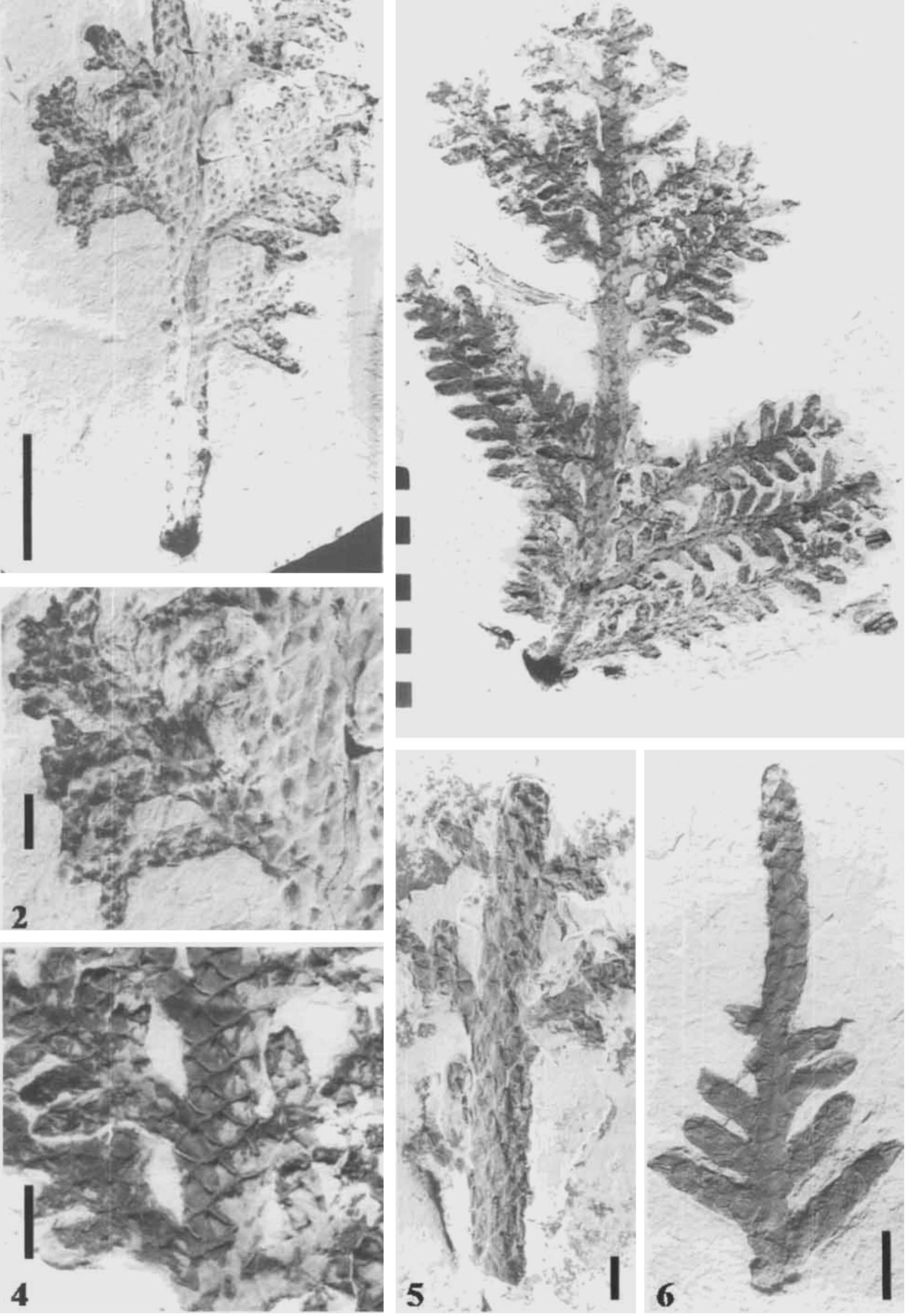
taceous of the Leiva region, Columbia, though without epidermis topography. These leaves are $80-120 \mathrm{~mm}$ long and $12 \mathrm{~mm}$ wide, constricted at the base, with 4-9 parallel unforked veins per $10 \mathrm{~mm}$ (Van Waveren et al. 2002).

At present the monotypic genus Lindleycladus is known from the northern hemisphere, more precisely from the Jurassic Yorkshire type locality (Harris 1979) and from the Cenomanian of the Bohemian Massif in Central Europe (Knobloch \& Kvaček 1997).

\section{Taphonomy and ecology}

Many of the conifer fossil remains are relatively fragmentary and partly abraded. Therefore, we assume that the majority of these plants did not grow close to the area of deposition, but in a hinterland which might have been relatively far away and the plant parts were probably transported via rivers to the area of deposition. Larger, almost completely preserved shoots of $\mathrm{Bra}$ chyphyllum obesum (Pl. 5: 3) by contrast speak against long distance transport. There is only little known about the ecology of conifers such as Lindleycladus. Among the Crato specimens are well preserved shoots that bear more than a dozen completely preserved leaves. One might deduct that the area where Lindleycladus grew was probably not very far away from the place where the remains were embedded in the sediment.

The anatomy of all these conifer remains allows general conclusions about the environment. All conifer taxa show rather thick, coriaceous leaves. These characters might be interpreted as adaptations to a warm to hot possibly seasonally dry climate in the palcoequatorial region. These assumptions on the ecology of the Crato conifers are confirmed when the habit and anatomy of other plant groups are analysed. Ferns, but also several angiosperm taxa show adaptions to drought: spiny hairs, etherial oil cells and coriacous leaves (Mohr \& Rydin 2002).

It is worth mentioning that a flora of the same age from Tunesia shares several taxa with the Crato flora, among them Podozamites and various angiosperms (Barale \& Ouaja 2001). There, Weichselia reticulata, a fern with many xeromorphic (Alvin 1974) features, might have grown near the seashore (Daber 1968). This supports the idea that also parts of the Crato flora might have grown and been deposited in a nearshore environment.

\section{Conclusions}

Conifers are common in the Early Cretaceous Crato flora. Beside a limited number of reproductive organs numerous foliage shoots occur, which are ascribed to two morphotypes. The excellent preservation of several of these specimens allows detailed morphological and anatomical studies of epidermal features. Based on these characters, members of two conifer families are identified.

Araucariaceae are represented by female cones and isolated cone scales (cf. Araucaria spec.) and possibly by Araucariostrobus spec., a juvenile conifer cone. Sterile shoots of the Brachyphyllum obesum-type which seem to be the most frequent conifer fossils of the Crato Flora are considered to belong to the Araucariaceae as well. Foliage shoots with large leaves are identified as Lindleycladus, that belongs to an unknown conifer family, are less common. This is the first account of this genus in South America, it has been described hitherto only from Europe.

Anatomical characters of the Crato conifer taxa discussed in this paper indicate a warm seasonally dry climate.

Plate 5. Brachyphyllum obesum Heer, 1881: impression specimens with a thin cover of iron oxide. 1-2, specimen showing 4 orders of branching, MfN PB 1999/472; 1, complete shoot (scale bar $=5 \mathrm{~cm}) ; 2$, detail of fig. 1 (scale bar $=1 \mathrm{~cm}) ; 3-4$, specimen showing opposite to (sub-) opposite arrangement of lateral branches, MfN PB 1999/452; 3, complete shoot (scale = $9 \mathrm{~cm}$ ): 4, detail of fig. 3: main axis densely covered with scaly leaves (scale bar $=1 \mathrm{~cm}$ ); 5 , shoot with more elongated leaves, MfN PB 1999/465 (scale bar = $1 \mathrm{~cm}) ; 6$. ultimate shoot with youngest growth rate, MfN PB 1999/466 $(\mathrm{scale}$ bar $=1 \mathrm{~cm})$.

Plate 6. Brachyphyllum obesum Heer, 1881: leaf epidermis, SEM photographs of the abaxial cuticle, specimen MfN PB $1999 / 468$. 1-6, inner view; 7-8, outer view; 1, epidermis topography of the median part of the leaf blade, preparation specimen MfN PB SEM 1999/468-1 (scalc bar $=100 \mu \mathrm{m}) ; \mathbf{2}$, detail of fig. 1: subsidiary cells of stomata (scale bar $=20 \mu \mathrm{m}) ; 3$, epidermis topography of the basal marginal part of the leaf lamina, preparation specimen MfN PB SEM 1999/468-3 (scale bar $=100 \mu \mathrm{m})$; 4. part of stomatal files showing randomly orientation of stomata, preparation specimen MfN PB SEM 1999/468-2 (scale bar $=30 \mu \mathrm{m}) ; \mathbf{5}$, detail of fig. 4: stomata with four and five subsidiary cells (scale bar $=10 \mu \mathrm{m}$ ); 6 , stomata, preparation specimen MfN PB SEM 1999/468-2 (scale bar $=10 \mu \mathrm{m}): 7$, single stoma, pit without plug, preparation specimen MfN PB SEM 1999/468-1 (scale bar = $10 \mu \mathrm{m}): 8$. stoma, narrow pit without papillac, preparation specimen MfN PB SEM 1999/468-1 (scale bar = $10 \mu \mathrm{m})$. 

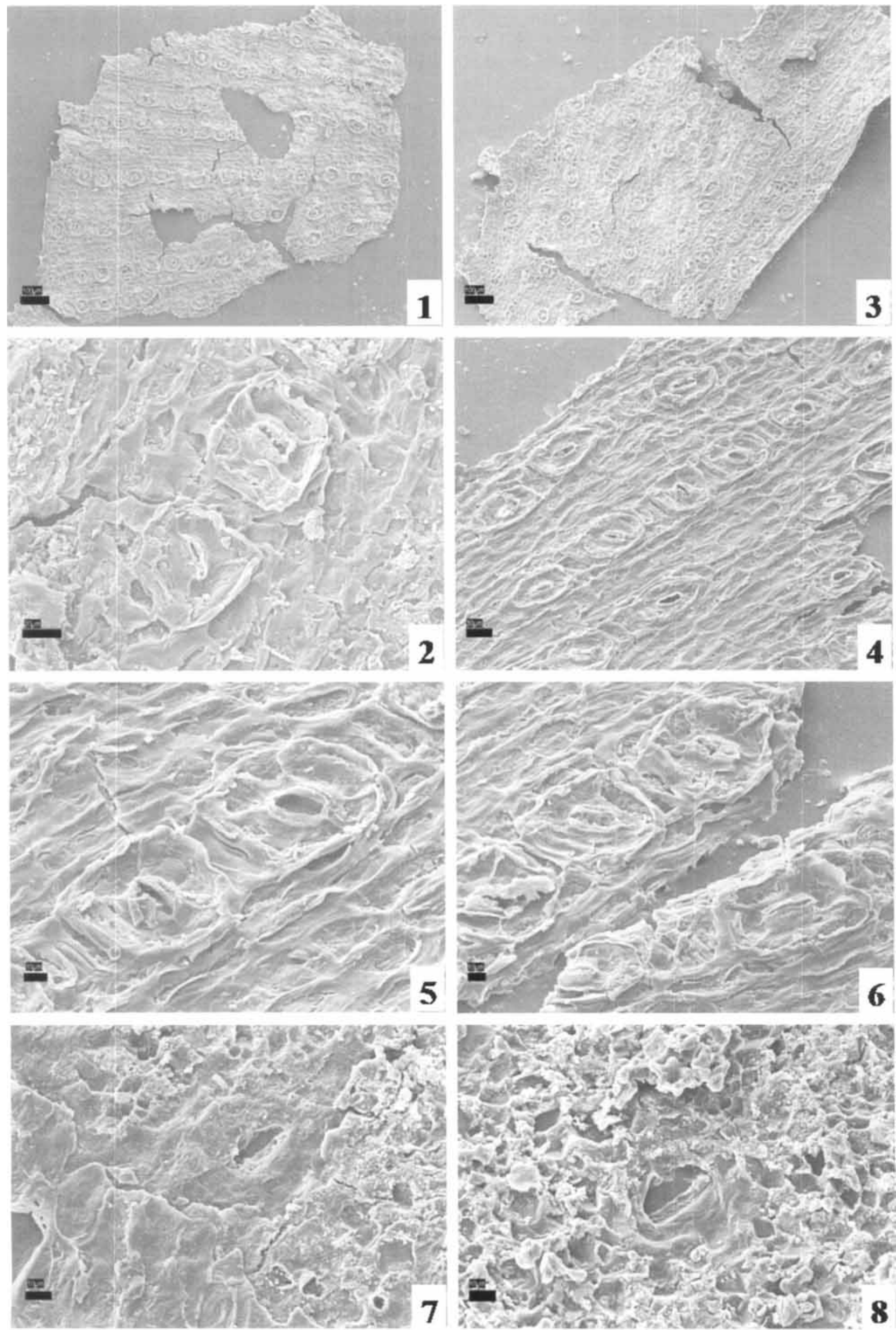

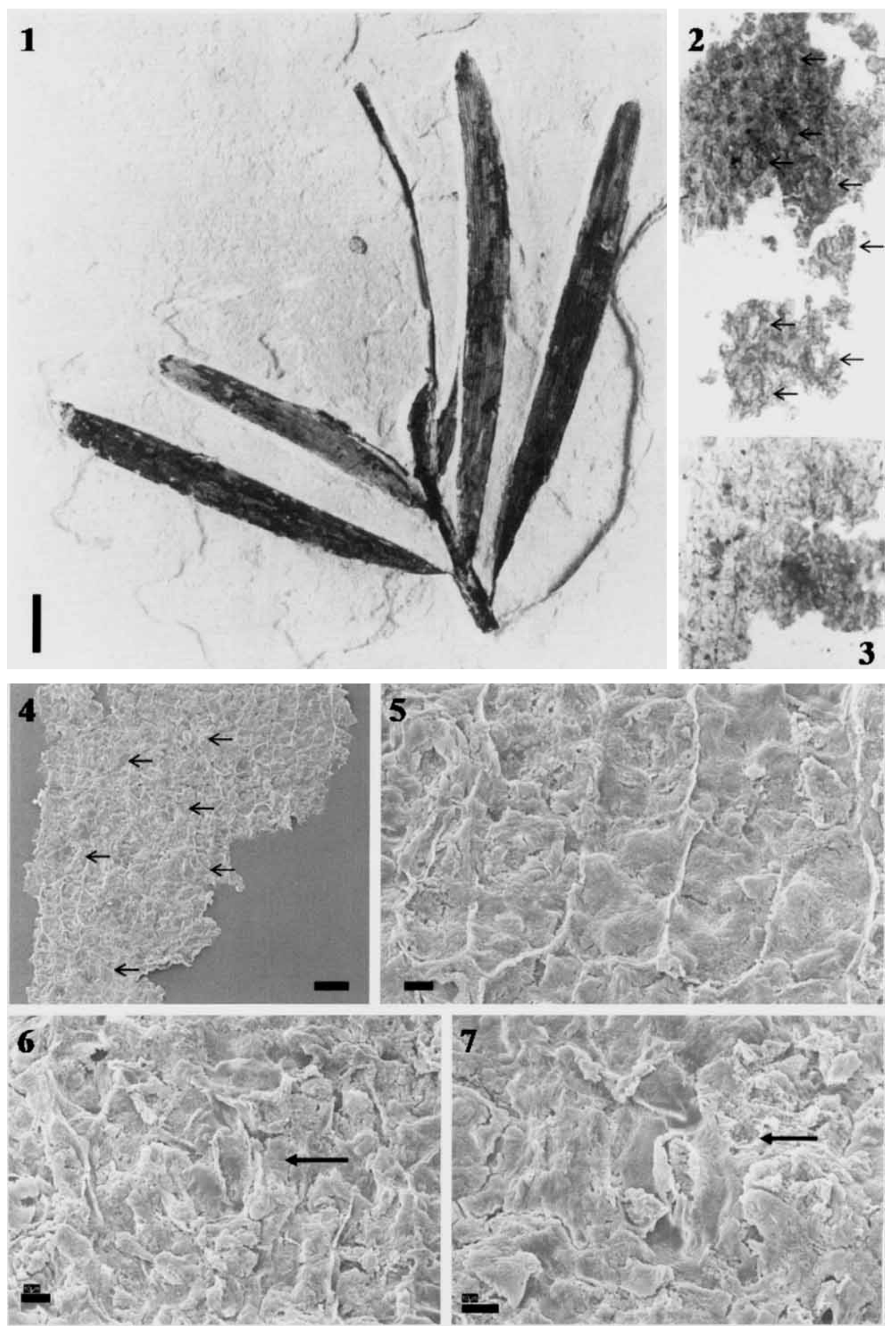

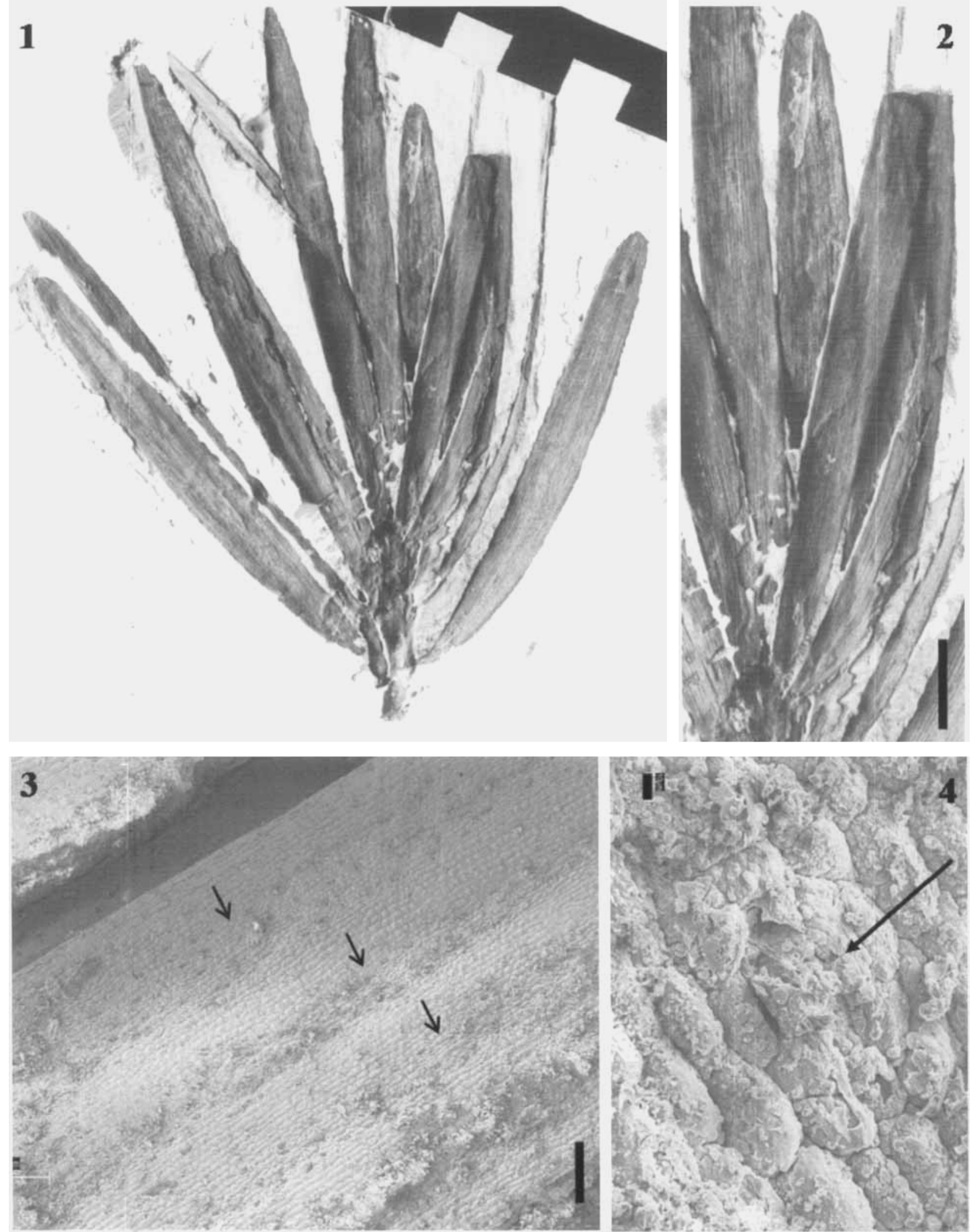

Plate 8. Lindleycladus spec.: shoot with iron oxide preservation of the leaf lamina and leaf epidermis topography, MfN PB 1999 442. 1, leafy shoot (scale with cm-division); 2 , detail of fig. 1 (scale bar $=1 \mathrm{~cm}$ ); 3-4, SEM photographs of abaxial side of a leaf, preparation specimen MN PB SEM 1999/442-7: 3, arrangement of stomata in bands of 3-5 files (arrows, scale bar $=200 \mu \mathrm{m}$ ); 4, stoma (arrow, scale bar $=10 \mu \mathrm{m})$.

Plate 7. Lindleycladus spec.: shoot with coalified organic matter on the leaf laminas and leaf epidermis topography, MfN PB 2002/1052. 1, leafy shoot (scale bar $=1 \mathrm{~cm}$ ); 2-3, LM photographs of the abaxial cuticle: 2 . arrangement of stomata (see arrows), preparation specimen MfN PB LM 2002/1052-1 $(100 \times)$; 3, ordinary epidermis cells, preparation specimen MfN PB LM 2002/1052-2 $(100 \times)$; 4-7, SEM photographs of the abaxial cuticle, inner side, preparation specimen MfN PB SEM 2002/1052-8; 4, arrangement of stomata (scale bar $=50 \mu \mathrm{m}) ; 5$. ordinary epidermal cells $($ scale bar $=10 \mu \mathrm{m}) ; 6$, stoma $($ arrow, scale bar $=10 \mu \mathrm{m}) ; 7$, stoma $($ arrow, scale bar $=10 \mu \mathrm{m})$. 


\section{Acknowledgements}

The authors thank Hans-Peter Schultze (Museum für Naturkunde, Berlin) for his encouragement and support in working on Crato material and Gloria Arratia (MfN, Berlin) for discussing palaeoenvironmental problems with us. Thanks to Carola Kunzmann (Museum für Mineralogie und Geologie, Dresden) for cuticle preparation for LM and SEM studies. The technical support was provided by Gabriela Drescher (MfN, Berlin) who assisted the SEM preparations and helped with the SEM pictures, and by Carola Radke (MfN, Berlin) who took the photographs of the fossils. Volker Wilde (Frankfurt/M.) was so kind to give the senior author, Lutz Kunzmann, access to the Crato specimens located at the Forschungsinstitut und Museum Senckenberg, Frankfurt/M. for comparison. David Lazarus (MfN, Berlin) was so friendly to check the English version of the manuscript. Two anonymous reviewers helped to improve the manuscript.

\section{References}

Alvin, K. L. 1974. Leaf anatomy of Weichselia based on fusainised material. - Palaeontology 17 (3): 587-598.

Arai, M., Coimbra, J. C. \& Silva-Teles, A. C. 2001. Sintese bioestratigraphica da Bacia do Araripe (nordeste do Brasil). In Barros, L. M., Nuvens, P. C., Figueira Coleçao J. B. M., Chapada do Araripe: 109-117, Crato.

Archangelsky, S. 1963. A new Mesozoic flora from Ticó, Santa Cruz Province, Argentina. - Bulletin of the British Museum (Natural History), Geology 8 (2): 47-92.

- 1966. New Gymnosperms from the Ticó Flora, Santa Cruz Province, Argentina. - Bulletin of the British $\mathrm{Mu}-$ seum (Natural History), Geology 13 (5): 259-295.

- 1968. On the genus Tomaxellia (Coniferae) from the Lower Cretaceous of Patagonia (Argentina) and its male and female cones. - Journal of the Linnean Society London, Botany 61: $153-165$.

- 1994. Comparative ultrastructure of three Early Cretaceous gymnosperm pollen grains: Araucariacites, Balmeiopsis and Callialasporites. - Review of Palaeobotany and Palynology 83: 185-198.

Barale, G. \& Ouaja, M. 2001. Découverte de nouvelles flores avec des restes à affinités angiospermiennes dans le Crétacé inférieur du Sud Tunesien. - Cretaceous Research 22: $131-143$.

Barreto, A. M. F., Bernardes-de-Oliveira, M. E. C., Dilcher, D. L., Mandarim-de-Lacerda, A. F. \& Viana, M. S. S. 2000. Early Cretaceous monocarpelar fruit of the Crato Member, Santana Formation, Araripe Basin, Northeastern Brazil. - Geosciencias 5: 121-124.

Berry, E. W. 1945. The Weichselia stage. In Singewald, J. T. (ed.) The origin of land plants and other papers. - John Hopkins University Studies Geology 14: 74-93.

Braun, C. F. W. 1843. Beiträge zur Urgeschichte der Pflanzen. In Münster, G. Graf zu. Beiträge zur Petrefactenkunde 6: 1-46, Taf. 9-13, Bayreuth.

Calder, M. G. 1953. A coniferous petrified forest in Patagonia. - Bulletin of the British Museum (Natural History), Geology 2: 97-140.

Cantrill, D. J. 1992. Araucarian foliage from the Lower Cretaceous of Southern Victoria, Australia. - International Journal of Plant Sciences 153 (4): 622-645.

Cantrill, J. D. \& Falcon-Lang, H. J. 2001. Cretaceous (late Albian) coniferales of Alexander Island, Antarctica. 2. Leaves, reproductive structures and roots. - Review of Palaeobotany and Palynology 115: 119-145.

Carruthers, W. 1869. On some Undescribed Coniferous Fruits from the Secondary Rocks of Britain. - Geological Magazin, decade 1, 6: 1-7.

Chambers, T. C., Drinnan A. N. \& McLoughlin, S. 1998. Some morphological features of wollemi pine (Wollemia nobilis: Araucariaceae) and their comparison to Cretaceous plant fossils. - International Journal of Plant Sciences 159: $160-171$.

Cookson, I. C. \& Pike, K. M. 1953. A contribution to the Tertiary occurrence of the genus Dacrydium in the Australian region. - Australian Journal of Botany 1: 474-484.

Daber, R. 1968. Weichselia-Stiehleria-Matoniaceae community within the Quedlinburg Estuary of Lower Cretaceous age. - Journal of the Linnean Society London, Botany 61: $75-85$.

Dernbach, U. \& Jung, W. 2002. Die Riesenzapfen aus Chubut, Argentinien. In Dernbach, U. \& Tidwell, W. D. (eds). Geheimnisse versteinerter Pflanzen, Faszination aus Jahrmillionen. 172-181; D'Oro; Heppenheim.

Dettmann, M. E., Molnar, R. E. \& Douglas, J. G. 1992. Australian Cretaceous terrestrial faunas and floras: biostratigraphic and biogeographic implications. - Cretaceous Research 13: 207-262.

Doyle, J. A. 1992. Revised palynological correlations of the lower Potomac Group (U.S.A.) and the Cocobeach sequence of Gabon (Barremian-Aptian). - Cretaceous Research 13: 337-349.

Duarte, L. 1985. Vegetais fosseis da Chapada do Araripe, Brasil. - Coletanea de trabalhos paleontológicos do VIII Congreso brasileiro de Paleontologia 1983, Paleontologia e Estatigrafia 2: 557-563.

Endlicher, S. 1847. Synopsis coniferarum. 368 pp., Apud Scheitlin \& Zollikofer, St. Gallen.

Enright, N. J. \& Hill, R. S. (eds) 1995. Ecology of Southern Conifers. 342 pp., Melbourne University Press, Carlton, Victoria.

Falcon-Lang, H. J. \& Cantrill, D. J. 2000. Cretaceous (late Albian) coniferales of Alexander Island, Antarctica: Wood taxonomy: a quantitative approach. - Review of Palaeobotany and Palynology 111: 1-17.

Farjon, A. 1998. World Checklist and Bibliography of Conifers. 298 pp., The Royal Botanic Gardens Kew, London.

Florin, R. 1963. The distribution of Conifer and Taxad genera in time and space. - Acta Horti Bergiana 20 (4): $121-312$.

Gaertner, J. 1788. De fructibus et seminibus plantarum, I. LII +520 pp., Academia Carolinae, Stuttgart.

Grauvogel-Stamm, L. 1978. La flore du Grès à Voltzia (Buntsandstein supérieur) des Vosges du Nord (France): Morphologie, anatomie, interprétations phylogénetique et paléogéographique. - Université Louis Pasteur de Strasbourg, Institut géologique, Mémoires 50: 1-225.

Harris, T. M. 1979. The Yorkshire Jurassic Flora, V. Coniferales. 166 pp., British Museum (Natural History), London.

Heer, O. 1881. Contributions à la flora fossile du Portugal. Communicaçoes Trabalhos Servicio Geologia Portugal, serie 4: $\mathrm{i}-\mathrm{xiv}+1-51$

- 1882. Die fossile Flora Grönlands, II. Theil, 1. Die Flora der Patootschichten. 46 pp., Vlg. Wurster, Zürich.

Henkel, J. B. \& Hochstetter, H. W. 1865. Synopsis der Nadelhölzer, deren charakteristische Merkmale nebst Andeutungen über ihre Cultur und Ausdauer in Deutschlands Klima. 446 pp., Cotta, Stuttgart.

Hill, R. S. \& Brodribb, T. 1999. Southern conifers in time and space. - Australian Journal of Botany 47: 639-693.

Jones, W. G., Hill, K. D. \& Allen, J. M. 1995. Wollemia nobilis, a new living Australien genus and species in the Araucariaceae. - Telopea $6(2-3): 173-176$.

Jussieu, A. L. de 1789. Genera plantarum secundum ordines naturales disposita, iuxta methodum in Horto regio Parisiensi exaratam anno 1774.499 pp., Herissant, Paris.

Knobloch, E. \& Kvaček, J. 1997. Bennettitalean and coniferalean (?) leaves from the Cretaceous (Cenomanian) of the Bohemian Massif, Central Europe. - Cretaceous Research 18: 567-586.

Krasser, F. 1921. Die von Ing. Karl Mandl (Wien) bei Nikolsk-Ussurijsk entdeckten Jurapflanzen hat folgenden 
Inhalt. - Königliche Akademie der Wissenschaften Wien, mathematisch-naturwissenschaftliche Klasse. Anzeiger 58: 219-222.

Kunzmann, L. 1999. Koniferen der Oberkreide und ihre Relikte im Tertiär Europas, ein Beitrag zur Kenntnis ausgestorbener Taxodiaceae und Geinitziaceae fam. nov. - Abhandlungen Staatliches Museum für Mineralogie und Geologie Dresden 45: 1-138.

Lima, M. R. de 1978. Palinologia da Formaçao Santana (Cretaceo do Nordeste do Brasil). I. Introduçao geologica e descriçao sistematicados esporos da Subturma Azonotriletes. - Ameghiniana 15: 333-365.

- 1979. Palinologia da Formaçao Santana (Cretaceo do Nordeste do Brasil). II. Descriçao sistematica dos espores da Subturma Zonotriletes e Turma Monoletes, e dos polens das Turmas Saccites a Aletes. - Ameghiniana 16: 27-63.

Lima, M. R. de, Oliveira-Babinski, M. E., Oliveira, J. B. 1989. Contribuçao a cronologia da Formaçao Santana etc. - XI. Congreso Brasileiro de Paleontologia. Resumos: 81.

Lindley. J. \& Hutton, W. 1836. The fossil flora of Great Britain; or, figures and descriptions of the vegetable remains found in a fossil state in this country. part $3.208 \mathrm{pp}$. pls. 157-230, London.

Maisey, J. G. 1991. Santana fossils. An illustrated atlas. 459 pp., TFH Publications, Neptune City, New Jersey.

Martill, D. M., Brito, P. M.. Wenz. M. \& Wilby. P. R. 1993. Fossils of the Santana and Crato Formations. Brazil. In Jarzembowski, E. A. (ed.). Palaeontological Association Field Guides to Fossils Series, 5: 1-159. The Palaeontological Association, London.

Menendez, C. A. \& Caccavari, M. A. 1966. Estructura epidermica de Araucaria nathorstii Dus. de Terciaro de Pico Quemado, Rio Negro, - Ameghiniana 4: 195-199.

Mohr, B. A. R. \& Bernardes-de-Oliveira, M. E. C. (in press) Endressinia brasiliana. a magnolialean angiosperm from the lower Cretaceous Crato Formation (Brazil). - International Journal of Plant Sciences.

Mohr, B. A. R., Bernardes-de-Oliveira. M. E. C., Barreto, A. M. F. \& Castro-Fernandes, M. C. 2004. Gnetophyte preservation and diversity in the early Cretaceous Crato Formation (Brazil). - VII. International Organization of Palaeobotany Conference (IOPC). Abstracts: 81. Bariloche, Argentina.

Mohr, B. A. R. \& Eklund, H. 2003. Araripia florifera, a magnoliid angiosperm from the Lower Cretaceous Crato Formation (Brazil). - Review of Palacobotany and Palynol. ogy 126: $279-292$.

Mohr, B. A. R. \& Friis, E. M. 2000. Early angiosperms from the Lower Cretaceous Crato Formation (Brazil), a preliminary report. - International Journal of Plant Sciences 161: $155-167$

Mohr, B. A. R. \& Rydin, C. 2002. Trifurcatia flabellata n. gen. n. sp., a putative monocotyledon angiosperm from the Lower Cretaceous Crato Formation (Brazil). - Mitteilungen aus dem Museum für Naturkunde in Berlin. Geowissenschaftliche Reihe 5: 335-344.

Nathorst, A. G. 1893. Pflanzenreste aus dem Neokom von Tlaxiaco. In Felix, J. \& Lenk, H. Beiträge zur Geologie und Paläontologie der Republik Mexico, Teil 2: 51-54, Schweizerbart. Leipzig, Stuttgart.

Némejc, F. 1950. The natural systematic of plants in the light of the present palaeobotanical documents. - Acta Musei Nationalis Pragae, ed. Geologica et Palaeontologica 6B (3): 183.

Němejc, F. \& Kvaček, Z. 1975. Senonian Plant macrofossils from the region of Zliv and Hluboká (near České Budéjovice) in South Bohemia. 82pp., Universita Karlova Praha, Prag.

Ohsawa, T., Nishida, H. \& Nishida, M. 1995. Yezonia, a new section of Araucaria (Araucariaceae) based on perminer- alized vegetative and reproductive organs of $A$. vulgaris comb. nov. from the Upper Cretaceous of Hokkaido, Japan. - Journal of Plant Research 108: 25-39.

Osborn J. M. Taylor, T. N. \& Lima, M. R. de 1993. The ultrastructure of fossil ephedroid pollen with gnetalean affinities from the Lower Cretaceous of Brazil. - Review of Palaeobotany and Palynology 77: 171-184.

Page. C. N. 1989. New and maintained genera in the conifer families Podocarpaceae and Pinaceae. - Notes of the Royal Botanic Garden Edinburgh 45 (2): 377-395.

- 1990. Coniferophytina. In Kubitzky, K. (ed.). The families and genera of vascular plants, Vol. 1 Pteridophytes and Gymnosperms: 282-362; Springer-Verlag, Berlin.

Pflug, H. D. 1953. Zur Entstehung und Entwicklung des angiospermiden Pollens in der Erdgeschichte. - Palaeontographica B 95: $60-171$.

Pons D. B., Berthou, P.-Y. \& de Campos, D. A. 1990. Quelques observations sur la palynologie de l' Aptien Supérieur et de l' Albien du Bassin d' Araripe (N.E. Brasil). Atlas do I Simposio sobre a Bacia do Araripe e Bacias Interiores do Nordeste Crato 1990: 241-252.

Pons D. B., Oliveira-Babinski, M. E. \& de Lima, M. R. 1992. Les Ephedrales de la Formation Santana, Cretacé Inferieur du Bassin d' Araripe (Brasil). - Fourth International Organization of Palaeobotany Conference, Abstracts 1992: 125

Regali. M. S. P. 1989. A ibade dos evaporitis da plataforma continental do Ceará, Brasil, e sua relação com os outros evaporitos dos Bacias nordestinas. In Oliveira-Babinski, M. E. C. B. (ed.). Paleobotânica e palinologia na America do Sul, VI Reuniao de Paleobotânicos e Palinologos, 1987. - Boletim IG-USP, Publição Especial, Instituto de Geociências, Universidade de São Paulo: 139--143.

Rydin, C., Mohr, B. A. R. \& Friis, E. M. 2003. Cratonia cotyledon gen. et sp. nov: a unique Cretaceous seedling related to Welwitschia. - Proceedings of the Royal Society of London B (Supplement), Biology Letters 270: 1-4. [PDF-File]

Salisbury, R. A. 1807. The Characters of several Genera in the Natural Order of Coniferae: with Remarks on their Stigmata, and Cotyledons. - Transactions of the Linnean Society London 8: $308-317$.

Spegazzini, C. 1924. Coniferales fosiles Patagonicas. - Anales de la Sociedad Cientifica de Argentina 98: 125-139.

Stockey. R. 1982. The Araucariaceae: an evolutionary perspective. - Review of Palaeobotany and Palynology 37: $133-154$.

- 1994. Mesozoic Araucariaceae: Morphology and systematic relationships. - Journal of Plant Research 107: 493-502.

Van Waveren, I. M., Van Konijenburg-van Cittert, J. H. A., Van der Burgh, J. \& Dilcher, D. L. 2002. Macrofloral remains from the Lower Cretaceous of the Leiva region (Columbia). - Scripta Geologica 123: 1-39.

Watson, J. 1977. Some lower Cretaceous conifers of the Cheirolepidiaceae from the U.S.A. and England. - Palaeontology 20 (4): 715-749.

- 1988. The Cheirolepidiaceae. In Beck, C. B. (ed.). Origin and Evolution of Gymnosperms: 382-447. Columbia University Press, New York.

Watson. J., Fisher, H. L. \& Hall, N. A. 1987. A new species of Brachyphyllum from the English Wealden and its probable female cone. - Review of Palaeobotany and Palynology 51: $169-187$.

Wilde, M. H. \& Eames, A. J. 1952. The ovule and seed of Araucaria bidwilli with discussion of the taxonomy of the genus, II. Taxonomy. - Annals of Botany, new series 16 $27-47$.

Windhausen, A. 1931. Geologia Argentina, part 2. 645 pp., Casa J. Peuser, Buenos Aires. 